\title{
Awareness about Otomycosis in Biotechnology Students in Bahauddin Zakaryia University
}

\author{
Muhammad Imran Qadir, and Mujahid Hussain* \\ Institute of Molecular Biology and Biotechnology, Bahauddin Zakariya University, Pakistan
}

*Corresponding author: Mujahid Hussain, Institute of Molecular Biology and Biotechnology, Bahauddin Zakariya University, Multan, Pakistan, Tel: 03341636762; E-mail: mujahidchandio93@gmail.com

Received: 22 Mar, 2019 | Accepted: 03 May, 2019 | Published: 10 May, 2019

Citation: Qadir MI, Hussain M (2019) Awareness about Otomycosis in Biotechnology Students in Bahauddin Zakaryia University. J Emerg Dis Virol 5(1): dx.doi.org/10.16966/2473-1846.148

Copyright: (C) 2019 Qadir MI, et al. This is an open-access article distributed under the terms of the Creative Commons Attribution License, which permits unrestricted use, distribution, and reproduction in any medium, provided the original author and source are credited.

\section{Abstract}

The objective of the present study was to assess knowledge about Otomycosis, a serious fungal disease of ear. It is characterized by pain and loss of hair. Aspergillus niger and Candida fungus are causative agents of otomycosis. Otomycosis can easily be diagnosed. Home remedies and ear drops containing medicine are used for the treatment of otomycosis. Otomycosis is a fungus disease, not viral infection or bacterial. It may be transmitted from one person to another through contact. It is not a genetic disease so it can't transmit from parents to offspring. Otomycosis required treatment. It was concluded from the present study that most of the students were familiar with the disease.

Keywords: Otomycosis; Fungus infection; Ear drops

\section{Introduction}

Otomycosis is a fungus infection that infects the ears. People living in tropical areas and warm condition can mostly affected by this disease. Otomycosis can also mostly affect the diabetic person and regularly swimming person. This disease is characterized by the inflammation, pain, hair loss, swelling ear redness, and narrow ear surface. Outer ear surface is mostly affected part of the body by this disease. Aspergillus niger and Candida fungus are causative agents of otomycosis [1-12]. Otomycosis occur due to unbalance concentration of acid and lipid in ear. Depending on infection, it is two types acute and sub-acute. Otomycosis affected mostly males as compared to female. With help of microscope and preparing fungus culture otomycosis infection can easily be diagnosed. Doctor can also diagnose otomycosis with help of otoscope. Doctor can take fluid from the ear and observe under the microscope can told whether it is fungus infection or not. Home remedies, ear drops and cleaning containing medicine can be used to treat the otomycosis disease. Doctor can clean infected ear by using rinses and other methods that slow down fungus infection. Otomycosis infection can also controlled by the antifungal drugs. Excessive use of antibiotics eardrops can reduce the fungus infection. Aspergillus and Candidiatus are isolated from otomycosis patients. By using otoscope with help of microscope, otomycosis can be diagnosed. Antifungal drugs such as miconazole and bifonazole are used to treat the fungus infection. Ear infection can also be fined by clinical examination $[1,2]$.

\section{Objective}

The objective of the present study was to assess knowledge about Otomycosis [5-9].

\section{Methods and Materials}

In this project, a questionnaire was prepared (Tables 1-4).

\section{Results}

In this project we collected information from different people about otomycosis. We observed that it is a fungal disease. About $91.66 \%$ males know that it is a fungal disease and only a few males told that it was not a fungal disease. We observed that mostly people recognized it was not a genetic diseases and it can't transfer from parents to offspring. About $91.66 \%$ male and $97.56 \%$ female recognized that it was not a metabolic disease. Otomycosis is not transferred through contact or blood decantation recognized by the $75 \%$ male and only $25 \%$ male recognized that it was transferred through contact or blood decantation. Medicines can be used to treat this infection recognized by the $91.66 \%$ male and only a few $8.33 \%$ males recognized that it was not treated by the medicines. Mostly people recognized that surgery is not required to treat this disease (Tables 5-8).

\section{Discussion}

Infection rate of otomycosis is greater in tropical countries. Otomycosis can be diagnosed on the base of symptom and laboratory work. Otomycosis occur due to presence of high humidity and heat. 
Table 1: Questionnaire to assess awareness about Otomycosis.

\begin{tabular}{|l|l|l|}
\hline \multicolumn{1}{|c|}{ Otomycosis } & Yes & No \\
\hline Fungal disease & & \\
\hline Bacterial disease & & \\
\hline Viral disease & & \\
\hline Metabolic disease & & \\
\hline Genetic disease & & \\
\hline
\end{tabular}

Table 2: Questionnaire to analyze awareness about ubiquity of otomycosis.

\begin{tabular}{|l|l|l|}
\hline \multicolumn{1}{|c|}{ Ever sustain from otomycosis } & Yes & No \\
\hline You & & \\
\hline Your family member & & \\
\hline Your relative & & \\
\hline Your neighbor & & \\
\hline Your friend & & \\
\hline
\end{tabular}

Table 3: Questionnaire to estimate vision about otomycosis.

\begin{tabular}{|l|l|l|}
\hline \multicolumn{1}{|c|}{ Otomycosis disseminated by } & Yes & No \\
\hline Contact or blood decantation & & \\
\hline From parents to progeny & & \\
\hline
\end{tabular}

Table 4: Questionnaire to evaluate perspective about hope for otomycosis

\begin{tabular}{|l|l|l|}
\hline Otomycosis may be medicated by & Yes & No \\
\hline Medicines & & \\
\hline Surgery & & \\
\hline No need of treatment & & \\
\hline
\end{tabular}

People that work in a dusty environment are more victims to the otomycosis. Cleaning of ear with contaminated finger tips can cause the inoculation of spores in the ear. Some people prefer self medication before going to physician and use many antibiotics that remove beneficial bacteria from the ear and encourage the growth of fungus in the ear. Fungus in the ear can be confirmed by ear swabs. Aspergillus and Candida species were isolated from fungus ear infection [3,4]. Otomycosis is a fungus disease, not viral infection or bacterial. It may be transmitted from one person to another through contact. It is not a genetic disease so it can't transmit from parents to offspring. Medicines can be used to treat this infection. Otomycosis required treatment.

\section{Conclusion}

It was concluded from the present study that most of the students were familiar with the disease.

\section{References}

1. Vennewald I, Klemm E (2010) Otomycosis: diagnosis and treatment. Clin Dermatol 28: 202-211.
Table 5: Questionnaire to assess awareness about otomycosis.

\begin{tabular}{|l|c|c|c|c|}
\hline \multirow{2}{*}{} & \multicolumn{2}{|c|}{ Male } & \multicolumn{2}{c|}{ Female } \\
\cline { 2 - 5 } & Yes & No & Yes & No \\
\hline Is Its viral disease? & $91.66 \%$ & $8.33 \%$ & $0.00 \%$ & $100 \%$ \\
\hline Is bacterial disease? & $0.00 \%$ & $100 \%$ & $0.00 \%$ & $100 \%$ \\
\hline Is it Fungal disease? & $91.66 \%$ & $8.33 \%$ & $100 \%$ & $0.00 \%$ \\
\hline Is it Genetic disease? & $8.33 \%$ & $91.66 \%$ & $0.00 \%$ & $100 \%$ \\
\hline Is it Metabolic diseases? & $8.33 \%$ & $91.66 \%$ & $2.43 \%$ & $97.56 \%$ \\
\hline
\end{tabular}

Table 6: Questionnaire to analyze awareness about ubiquity of otomycosis.

\begin{tabular}{|l|c|c|c|c|}
\hline \multirow{2}{*}{$\begin{array}{c}\text { Ever suffered from } \\
\text { fungal ear infection }\end{array}$} & \multicolumn{2}{|c|}{ Male } & \multicolumn{2}{c|}{ Female } \\
\cline { 2 - 5 } & Yes & No & Yes & No \\
\hline Are you? & $8.33 \%$ & $91.66 \%$ & $0.00 \%$ & $100 \%$ \\
\hline Ever your family? & $8.33 \%$ & $91.66 \%$ & $0.00 \%$ & $100 \%$ \\
\hline Ever your relative? & $33.33 \%$ & $66.66 \%$ & $0.00 \%$ & $100 \%$ \\
\hline Ever your neighbor? & $58.33 \%$ & $41.66 \%$ & $29.26 \%$ & $70.32 \%$ \\
\hline Ever your friend? & $0.00 \%$ & $100 \%$ & $0.00 \%$ & $100 \%$ \\
\hline
\end{tabular}

Table 7: Questionnaire to evaluate perspective about hope for Otomycosis.

\begin{tabular}{|l|c|c|c|c|}
\hline \multirow{2}{*}{\multicolumn{1}{c|}{$\begin{array}{c}\text { Otomycosis infection } \\
\text { transmission }\end{array}$}} & \multicolumn{2}{c|}{ Male } & \multicolumn{2}{c|}{ Female } \\
\cline { 2 - 5 } & Yes & No & Yes & No \\
\hline Through blood? & $25 \%$ & $75 \%$ & $7.31 \%$ & $92.68 \%$ \\
\hline $\begin{array}{l}\text { Can be transmitted from parent } \\
\text { to offspring? }\end{array}$ & $16.66 \%$ & $83.33 \%$ & $0.00 \%$ & $100 \%$ \\
\hline
\end{tabular}

Table 8: Questionnaire to assess awareness about otomycosis.

\begin{tabular}{|l|c|c|c|c|}
\hline \multirow{2}{*}{ Otomycosis infection cured by? } & \multicolumn{2}{|c|}{ Male } & \multicolumn{2}{c|}{ Female } \\
\cline { 2 - 5 } & Yes & No & Yes & No \\
\hline By medicines? & $91.66 \%$ & $8.33 \%$ & $90.24 \%$ & $9.75 \%$ \\
\hline By surgery? & $8.33 \%$ & $91.66 \%$ & $0.00 \%$ & $100 \%$ \\
\hline Can be cured or not? & $0.00 \%$ & $100 \%$ & $0.00 \%$ & $100 \%$ \\
\hline
\end{tabular}

2. Munguia R, Daniel SJ (2008) Ototopical antifungals and otomycosis: a review. Int J Pediatr Otorhinolaryngol 72: 453-459.

3. da Silva Pontes ZB, Ferreira Silva AD, de Oliveira Lima E, de Holanda Guerra M, Cavalcanti Oliveira NM, et al. (2009) Otomycosis: a retrospective study. Braz J otorhinolaryngol 75: 367-370.

4. Barati B, Okhovvat SAR, Goljanian A, Omrani MR (2011) Otomycosis in central Iran: a clinical and mycological study. Iran Red Crescent Med J 13: 873-876.

5. Qadir MI, Javid A (2018) Awareness about Crohn's Disease in biotechnology students. Glo Adv Res J Med Med Sci 7: 62-64.

6. Qadir MI, Saleem A (2018) Awareness about ischemic heart disease in university biotechnology students. Glo Adv Res J Med Med Sci 7: 59-61.

7. Qadir MI, Ishfaq S (2018) Awareness about hypertension in biology students. Int J Mod Pharma Res 2: 8-10. 
8. Qadir MI, Mehwish, Abdul Raheem (2018) Awareness about psoriasis disease. Int J Mod Pharma Res 2: 17-18.

9. Qadir MI, Shahzad R (2018) Awareness about obesity in postgraduate students of biotechnology. Int J Mod Pharma Res 2: 14-16.

10. Qadir MI, Rizvi M (2018) Awareness about thalassemia in post graduate students. MOJ Immunol 6: 163-165.

11. Qadir MI, Ghalia BA (2018) Awareness survey about colorectal cancer in students of M. Phil Biotechnology at Bahauddin Zakariya University, Multan, Pakistan. Nov Appro Can Study 1.

12. Qadir MI, Saba G (2018) Awareness about intestinal cancer in university student. Nov Appro Can Study 1. 